International Journal of English Literature and Social Sciences
Vol-6, Issue-5; Sep-Oct, 2021

Peer-Reviewed Journal

\title{
Re-Reading Smarthavicharam
}

\section{Vandhana Nair N}

PhD Scholar, Srinivas University, Mangalore, India

Received: 03 Aug 2021; Received in revised form: 03 Sep 2021; Accepted: 10 Sep 2021; Available online: 16 Sep 2021

(C)2021 The Author(s). Published by Infogain Publication. This is an open access article under the CC BY license

(https://creativecommons.org/licenses/by/4.0/).

\begin{abstract}
Smarthavicharam is a ritually sanctioned procedure of ostracizing an accused women from her Namboodiri community for sexual offences based on sankarasmrithi. With this article I would like to put forth the argument that the world hasn't moved much forward from the old smarthavicharam since the recent cases like the then celebrities swapna and saritha are the best examples. The cases won't be different in the future too.
\end{abstract}

Keywords - smarthavicharam, ritual, ostricize, namboodiri women, sexual offences, antherjanam, thathrikutty, trial and retrial, aphans, sambandham.

Smarthavicharam is a ritually sanctioned procedure of ostracizing an accused Namboodiri woman from her community for sexual offence based on Sankarasmrithi.

During CE 1200 -CE 1900, the Namboodiri's held sway in Kerala society's caste hierarchy. In order to retain the possession of their huge land holdings and to ensure it was not subdivided, the patriarchal Namboodiri caste permitted only the eldest son in the family to marry from among the Namboodiris and he was permitted multiple marriages in order to accommodate Namboodiri women who were not permitted to marry outside the caste(Bhaskaranunni 59). This led to psychological, sexual and social dissatisfaction within the community as young women and younger brothers in the community were denied their rights for normal lives. While the younger brothers(aphans) could have sexual relations (sambandham)with lower caste Nair women, Namboodiri women had no such opportunity. The reactions to these led to an increasing number of deviants from the norms which were termed/considered as sexual offences.

Agnisakshi by Lalithambika Antherjanam deals with the theme of Thathrikutty's smarthavicharam. The proposed paper intend to explore this concept from two different perspectives -first, a historical perspective of how things turned out, and second interrogating it using contemporary 'female phase' foregrounded by Showalter. Agnisakshi portrays Thathrikutty as reacting against the oppression of women by the Namboodiri community. The text is based on the historical trial of Thathrikutty who was accused of sexual relations with sixty five men. The verdict of the trial had to be delayed and a re-trial was ordered as per the provisions of modern day jurisprudence. The king who ordered the trial was also implicated in it by later discourses, thanks to a coterie of dissidents. The trial records and documents are available in Cochin Archives and the regional newspapers of the time.

On the other handthe feminist perspective looks at Thathrikutty as the then 'feminist', who went on to claim her identity against the patriarchy, her attempt at prostitution was looked at as her retaliation against the system and thereby as the feminist phase in history, however the proposed dissertation intend to re-read Smarthavicharam notas part of the feminist phase as believed by literature discourses but as part of the female phase that Showalter speaks of, wherein both male and female have their own preferences which does not make one superior to the other. There comes an autonomous turn to things.

The imperative for this proposal was drawn by the fact that the period between CE 1890-CE 1924 witnessed the most cases on Smarthavicharam along with the Namboodiri women willingly wanting to be ostracized. The importance of the topic lies in where the another face of smarthavicharam acts in Kerala. The practices done 
with "saritha" and "swapna" Is not different. Here it's evident that the victims of male vulgurnesses also faces the same isolation.

\section{REFERENCES}

[1] Antherjanam, Lalithambika. Agnisakshi. Kottayam: D C Books, 1976. Print.

[2] Bhaskaranunni,P. Smarthavicharam. Kottayam: NBS, 2000. Print.

[3] Showalter, Elaine.A Literature of Their Own.1977.

[4] Chakyar, AMN. Avasanathe Smartha Vicharam. Trans. KK Sankaran Namboodiri. 